\title{
Spomienka na profesora MUDr. Karla Horkého, DrSc., FACP (Hon), FEFIM
}

*11. 5. 1933 - +8. 8. 2016

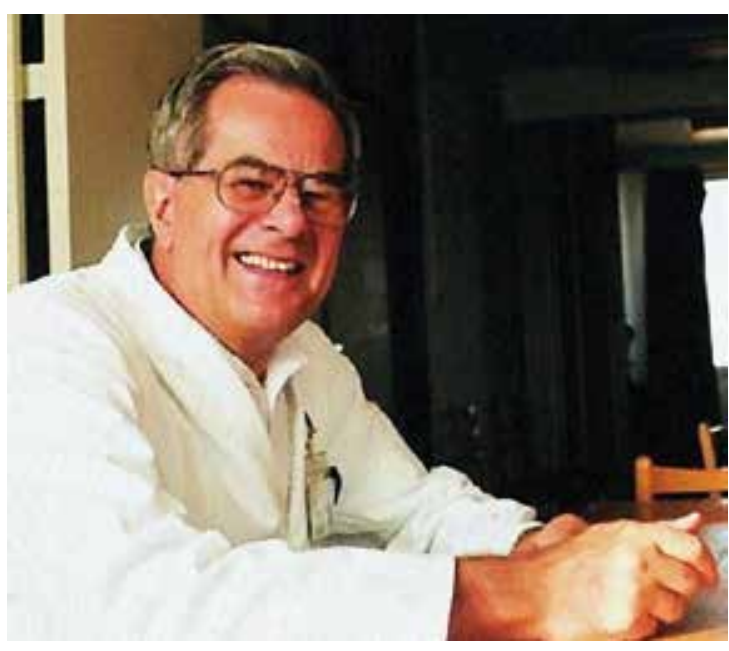

Prof. MUDr. Karel Horký, DrSc., sa narodil 9. mája 1933 v Brne. Štúdium medicíny ukončil roku 1957 na Lekárskej fakulte Masarykovej univerzity v Brne. Po promócii pôsobil na Internom oddelení nemocnice $v$ Dečíne. $V$ roku 1961 prešiel na III. internú kliniku Fakulty všeobecného lekárstva Univerzity Karlovej v Prahe (FVL UK). Pracoval pod vedením prof. J. Charváta a neskôr prof. V. Pacovského. V rokoch 1969-1970 absolvoval dlhodobý a v roku 1984 opakovaný pobyt na Clinical Research Institute of Montreal $v$ Kanade. $V$ rámci všeobecného vnútorného lekárstva, ktoré vždy zdôrazňoval ako integrujúci odbor, sa venoval hypertenzii, endokrinológii a kardiológii [1,2].

S prof. Karolom Horkým sme sa zoznámili v 70. rokoch 20. storočia na konferenciách dialyzačných a transplantačných pracovníkov v Žinkovoch, v juhozápadných Čechách, ktoré organizoval prof. K. Opatrný z Plzne. Prof. K. Horký tam prednášal o systéme renín-angiotenzín-aldosterón pri hypertenzii a pri iných chorobách $v$ rámci vnútorného lekárstva. $V$ tej dobe začala naša spolupráca, ktorá trvala mnoho rokov a naše priatel'stvo až do konca jeho života. Prof. Horký v Laboratóriách pre endokrinológiu a metabolizmus III. internej kliniky FVL UK v Prahe, na ktorej určitú dobu pracoval ako samostatný vedecký pracovník, zabezpečoval vyšetrenie parametrov systému renín-angiotenzín-aldosterón a arginín-vazopresín v plazme u našich chorých v rôznych štádiách náhleho zlyhania obličiek a u niektorých chorých s akútnymi otravami, ktorí boli liečení hemoperfúziou. Biologický materiál sme osobne transportovali letecky z Košíc do Prahy. Výsledky našich spoločných vedeckovýskumných štúdií boli prezentované na domácich a zahraničných kongresoch a publikované doma a v zahraničí [3-8]. V júni roku 1984 prvý autor tejto spomienky spolu s Karolom Horkým obhájili vedeckú hodnost' doktor lekárskych vied (DrSc.) na III. internej klinike FVL UK v Prahe za predsedníctva prof. V. Pacovského, prednostu tejto kliniky, a prof. T. R. Niederlanda, prednostu III. internej kliniky LF UK v Bratislave. Nasledujúci deň po obhajobách sa konala slávnostná večera s našimi oponentami a niektorými priatel'mi v reštaurácii „U Malírưu na Maltézskom námestí v Prahe na Malej Strane. Diplomy Doktor lekárskych vied boli odovzdané na univerzitnej pôde prvému autorovi tejto správy v Bratislave a prof. Horkému v Prahe. Naša spolupráca a spoločné stretnutia pokračovali aj počas jeho pôsobenia ako prednostu II. internej kliniky FVL UK v Prahe (1990-1998).

Prof. Horký publikoval počas svojho aktívneho života viac ako 410 pôvodných prác $v$ recenzovaných časopisoch. V roku 2003 bol hlavným editorom Lekárskeho repetitória, ktoré bolo vel'mi kladne ohodnotené v rámci klinickej medicíny $[1,2,9]$. Svoje vedomosti a bohaté skúsenosti z celej internej medicíny zúročil ako člen redakčných rád významných odborných časopisov, ako sú European Journal of Internal Medicine, Endocrine Regulation, Cor et Vasa a Vnitřní lékařství [8]. Okrem toho mal za sebou významnú pedagogickú činnost'. Prednášal poslucháčom lekárskej fakulty a v rokoch 1990-1991 bol prodekanom 1. LF UK v Prahe. V rokoch 1991-2005 pôsobil ako predseda Českej internistickej spoločnosti Českej lekárskej spoločnosti Jana Evangelisty Purkyne.

Napriek tomu, že sme boli čiastočne informovaní o jeho zdravotných tažkostiach v poslednej dobe, správa o jeho smrti, dňa 8. augusta 2016, nás velmi zasiahla $[10,11]$. Na poslednej rozlúčke s prof. MUDr. Karolom Horkým, DrSc., v Prahe-Strašniciach, sa osobne zúčastnil aj prvý autor tohto nekrológu.

\section{Milý Karel,}

zostaneš navždy v našej pamäti ako jeden z našich najvýznamnejšich spolupracovníkov a priatelov.

Čest'Tvojej pamiatke!

\section{Miroslav Mydlík, Katarína Derzsiová za kolegov a priatelov zo Slovenska}

\section{Literatúra}

1. Aschermann M. Významné životní jubileum prof. MUDr. Karla Horkého, DrSc. Cor Vasa 2013; 55(2 Kardio): 252.

2. Vitoušová E. Prof. MUDr. Karel Horký, DrSc.: Rozhovor. Postgrad Med 2002; 4(8): 822-825. 
3. Horký K, Gregorová I, Mydlík M et al. Plazmatická koncentrace aldosteronu u nemocných s akutní renální nedostatečností. 118-122. In: Opatrný K (ed.). Sborník prací Význam radioimunologické analýzy pro vyšetřování nemocných s ledvinnou nedostatečností. II. díl. Žinkovy 13. 5. 1977. Škoda Plzeň 1978.

4. Mydlík $M$, Horký $K$, Jonáš $P$ et al. Plasma renin activity and plasma aldosterone in acute renal failure. 463-470. In: Watschinger B (ed). 3. Donausymposium für Nephrologie. Linz, 22.-24. IX. 1978. Bindernagel: Friedberg/Hessen: 1979. ISBN 9783921418307.

5. Mydlík M, Horký K, Jonáš $P$ et al. Plasma renin activity and plasma aldosterone in acute renal failure. Int Urol Nephrol 1980; 12(1): 83-90.

6. Mydlík M, Derzsiová K, Horký K et al. The side effects of charcoal haemoperfusion in acute renal poisoning and during regular dialysis treatment. 242-248. In: Watschinger B (ed). Proc. of 5. Donausymposium für Nephrologie. Linz, Österreich 12. - 14. September 1980. Schendl: Wien 1981.

7. Mydlík M, Horký K, Derzsiová K et al. Arginín-vazopresín v plazme a osmolalita v sére pri náhlom zlyhaní obličiek. Čas Lék Čes 1983; 122(19): 587-590.
8. Mydlík M, Derzsiová K, Buček J et al. Use of charcoal haemoperfusion in acute poisonings. Life support systems. J Europ soc artif Organs Proc X Ann Meeting ESAO 1983; 1(Suppl 1): 53-56.

9. Horký K (ed). Lékařské repetitorium. Galen: Praha 2003. ISBN 80-7262-241-2.

10. Češka R. In memoriam pana profesora Karla Horkého. Vnitř Lék 2016; 62(9): 683.

11. Widimský J Jr. Zemřel profesor Karel Horký. Čas Lék Čes 2016; 155(5): 278.

\section{prof. MUDr. Miroslav Mydlík, DrSc.}

\miroslav.mydlik@unlp.sk

Ing. Katarína Derzsiová

IV. interná klinika LF UPJŠ a UN L. Pasteura Košice, Slovenská republika

Doručeno do redakce 15. 12. 2016 